\title{
Effect of different fertilization managements on nitrate accumulation in a Mollisol of Northeast China
}

\author{
Li Yan ${ }^{1,2}$, Jinjing Zhang ${ }^{1 *}$, Zhidan Zhang ${ }^{1}$, Ahmed Mohamed Abdelrahman and Qiang Gao ${ }^{1 *}$
}

\begin{abstract}
Background: In a continuous spring maize system in Northeast China, the accumulation and succession characteristics of nitrate in Mollisol with four fertilization treatments, including no fertilization (CK), farmers' conventional fertilization (FC), recommendation fertilization (RF), and controlled release fertilizer application (CRF), were compared over a 6-year field plot trial.

Results: On average, the RF and CRF treatments decreased nitrate nitrogen by 16.6 and $39.5 \%$ in the 0-90 cm soil layer, respectively, and maintained a relatively high maize grain yield, as compared to the FC treatment. The accumulation of nitrate nitrogen was more obvious in the CRF treatment compared with the other fertilizer treatments under the arid climate. However, the high precipitation resulted in the leaching of nitrate nitrogen into the deeper soil layer in all the fertilizer treatments. The maximum of nitrate nitrogen in the $0-90 \mathrm{~cm}$ soil layer was $81.4 \mathrm{~kg} \mathrm{~N} / \mathrm{ha}$ at a nitrogen fertilizer rate of $250 \mathrm{~kg} \mathrm{~N} / \mathrm{ha}$ in the long-term trial, which was within the rational and safe level for groundwater.

Conclusions: The best fertilization strategy to decrease nitrate accumulation in soil should consider both soil characteristics and precipitation.
\end{abstract}

Keywords: Nitrate, Recommendation fertilization, Controlled release fertilizer, Long-term experiment

\section{Background}

Maize is a major cereal crop worldwide and accounts for over $35 \%$ of global food production. China, as one of the golden maize belts in the world, is the second largest maize-producing country, with a total growing area of $3.05 \times 10^{7}$ ha recorded in 2009 [8], which was mainly concentrated in North, Northeast, and Southwest China [26]. The spring maize zone of Northeast China is one of the most important areas of food production in China, and maize yield from this region has reached $35 \%$ of the total maize production in China [37, 39]. Nitrogen is one of the main plant nutrients and is essential for effective plant growth [36]. Maize, as a high-yield crop, is frequently applied with amounts of $\mathrm{N}$ fertilizer. The contamination of surface and groundwater by nitrate

\footnotetext{
*Correspondence: zhangjinjing@126.com; gaoqinglunwen@163.com

${ }^{1}$ College of Resource and Environmental Science, Jilin Agricultural

University, Changchun 130118, People's Republic of China

Full list of author information is available at the end of the article
}

accumulation in soil is a major environmental concern in China. The reason could be due to the excessive nitrogen fertilizer application, especially over the past two decades. In Northeast China, in 2012, 10.7 million hectares of land were cultivated with maize [28]. The increasing application rate of $\mathrm{N}$ fertilizer had no discernible increase on yield parameters, which however resulted in substantial $\mathrm{N}$ volatilization and $\mathrm{N}$ residues in soils $[15,18,29]$.

Loepez-Bellido et al. [19] reported that in a typical rainfed area of southern Spain, the nitrate nitrogen residue in soil increased with time, accumulated mostly in the $30-60 \mathrm{~cm}$ soil layer, and additionally the average nitrate residue was $82,88,116$ and $145 \mathrm{~kg} \mathrm{~N} / \mathrm{ha}$ in the $0-90 \mathrm{~cm}$ soil layer at the $\mathrm{N}$ rates of $0,50,100$ and $150 \mathrm{~kg} \mathrm{~N} / \mathrm{ha}$, respectively. Wang [35] analyzed more than 800 records in 120 papers published over the last 30 years concerning nitrate accumulation in soils in China and reported that this phenomenon peaked at $200 \mathrm{~kg} \mathrm{~N} / \mathrm{ha}$ in $0-100 \mathrm{~cm}$ soil layer as the average for field crops such as maize, 
wheat, and rice in China and even $700 \mathrm{~kg} \mathrm{~N} / \mathrm{ha}$ in vegetable crops. Kou et al. [16] noted that nitrate accumulation in the $0-90 \mathrm{~cm}$ soil layer was $221-275 \mathrm{~kg} \mathrm{~N} / \mathrm{ha}$ for the wheat-maize rotation system in North China. However, Roth and Fox [25] reported that the residue of soil nitrate ranged from 41 to $138 \mathrm{~kg} \mathrm{~N} /$ ha in $0-120 \mathrm{~cm}$ after harvesting a maize crop which was fertilized by economic $\mathrm{N}$ rate.

Regarding ecosystems and from an ecological standpoint, the negative effects of nitrate residues can be reduced by studying the efficiency of $\mathrm{N}$ fertilizer in soil [20]. On the basis of crop plants, $\mathrm{N}$ efficiency was affected by applying different $\mathrm{N}$ fertilizer rates and by adjusting the timing of fertilizer application $[1,45]$. Gao et al. [10] reported that on average, the nitrogen application rate was $207 \mathrm{~kg} / \mathrm{ha}$ in Northeast China, and $220 \mathrm{~kg} / \mathrm{ha}$ in the central zone of Jilin Province in the continuous spring maize system in 2008; furthermore, the phenomenon of excessive nitrogen application $(\mathrm{N}>240 \mathrm{~kg} / \mathrm{ha})$ reached $40 \%$. Over-application of $\mathrm{N}$ fertilizer has become a common practice in maize production systems and has led to nutrient imbalances and inefficient fertilizer applications, and has resulted in negatively impacting the environment $[3,15]$. Soil testing has been developed as a means of improving fertilizer use efficiency in China. He et al. [12] conducted multiple-point field trials based on soil testing in North Central China and showed that soil testbased fertilizer recommendations could increase wheat and maize yield and improve fertilizer use efficiency. Furthermore, controlled release fertilizer technologies, by regulating the time of $\mathrm{N}$ release from fertilizers, has the potential to reduce leaching losses of nitrate in soil [14, 27, 30, 31]. Many studies have found that the application of controlled release $\mathrm{N}$ fertilizer significantly increased the NUE and yields of crops [11, 40]. Zhang et al. [42] reported that the yields of both rice and oilseed rape with applied CRU increased by $6.9 \%$ each, even when the CRU rate was reduced by $20 \%$ relative to common urea. Dinnes et al. [6] reported that splitting fertilization could reduce the losses of nitrates from crop plants. The European Union recommends that control should be exercised over the amount of fertilizer applied; however, they do not specify limits the safe amount of fertilizer applied depends on climatic conditions, the nitrogen absorption capacity of crops, the soil $\mathrm{N}$ content as well as the frequency and timing of the application [2].

Many studies have reported that excessive $\mathrm{N}$ input resulted in higher nitrate nitrogen residues in soil [4, 32]. However, information on nitrate accumulation in soil, based on reducing the nitrogen rate and controlled release fertilizer ensuring yield, is still scarce in Northeast China. Therefore, the objectives of this 6-year field research in Northeast China were to evaluate the effects of reduced nitrogen rate and controlled release fertilizer (1) on maize yield and $\mathrm{N}$ uptake, (2) on nitrate accumulation in soil, and (3) on nitrate movement in different soil profiles.

\section{Methods \\ Site description and experimental design}

The field trials were conducted from 2004 to 2009 in a Mollisol in Dehui (DH) city, Jilin Province, Northeast China $\left(44^{\circ} 33^{\prime} \mathrm{N}, 125^{\circ} 43^{\prime} \mathrm{E}\right)$. The climate is characterized by a temperate continental monsoon. The contents of soil organic matter, total $\mathrm{N}$, Olsen phosphorus $(\mathrm{P})$, and available potassium $(\mathrm{K})$ in the upper $30-\mathrm{cm}$ soil layer were $34 \mathrm{~g} / \mathrm{kg}, 2.62 \mathrm{~g} / \mathrm{kg}, 41.3 \mathrm{mg} / \mathrm{kg}$ and $172.9 \mathrm{mg} / \mathrm{kg}$, respectively. Nitrate nitrogen in the $0-90 \mathrm{~cm}$ soil layer was $38.2 \mathrm{mg} / \mathrm{kg}$, while the $\mathrm{pH}$ was 7.4 .

The trial sites were cultivated with continuous spring maize planted from May to October each year for a duration of 6 years. Four nitrogen fertilization management treatments (NMTs) were conducted in a randomized block design with four replications, namely block treatment with no nitrogen fertilizer (CK), farmer conventional treatment with chemical fertilizer-urea by splitting fertilization (FC) and applying high $\mathrm{N}$ rate (which was applied in more than $40 \%$ of farmers' fields in Dehui county), recommendation fertilization treatment with low $\mathrm{N}$ rate in which the $\mathrm{N}$ rate was calculated by soil testing and yield target (RF), and finally controlled release fertilizer (CRF) which is a mixture of common urea and 4-month longevity of the polymer coating of sulfur-coated urea (hybrid coatings with sulfur and a thin polymer coating containing $35 \% \mathrm{~N}$, made by Luyue chemical Co. Ltd., Shandong, China); the N ratio was 1:2. Nitrogen release rate of polymer-coated urea in $25{ }^{\circ} \mathrm{C}$ water is shown in Fig. 1. The nitrogen fertilizer rate of CRF treatment was $20 \%$ less than that of FC treatment. Eighty $\mathrm{N} \mathrm{kg} / \mathrm{ha}$ of the nitrogen fertilizer, and all phosphorus, potassium fertilizer in FC and RF treatments and all NPK fertilizers in CRF treatment were uniformly plowed into the soil before broadcasting, and other fertilizers as top-dressing were applied between the V6 and V7 stages. Phosphorus and potassium fertilizers were triple superphosphate (P $46 \%$ ) and potassium chloride (K $60 \%$ ), respectively. The four treatments were administered by the local farmers' traditional planting practices which included planting density, sowing, and the harvest time, as well as fertilizer application periods. Each plot was $10 \mathrm{~m} \times 4 \mathrm{~m}$ with 6 rows of maize spaced $0.66 \mathrm{~m}$ apart. Nitrogen, phosphorus, and potassium fertilizer rates of each treatment are shown in Table 1. The same and typical spring maize hybrids in each year in Northeast China were used. Plant density each year was 55,000 plants/ha. The 6-year trial was conducted under rain-fed condition. 


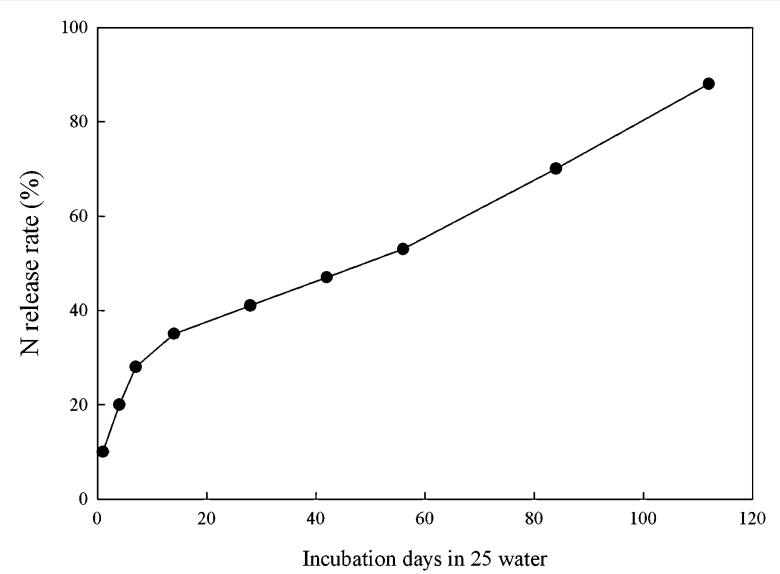

Fig. $1 \mathrm{~N}$ accumulative release curve of control release fertilizer

Table 1 Fertilizer rate and fertilization information of different treatments

\begin{tabular}{lclll}
\hline Treatment & $\mathbf{N}(\mathbf{k g} / \mathbf{h a})$ & $\mathbf{P}_{\mathbf{2}} \mathbf{O}_{\mathbf{5}} \mathbf{( k g / h a )}$ & $\mathbf{K}_{\mathbf{2}} \mathbf{O}(\mathbf{k g} / \mathbf{h a})$ & Fertilization \\
\hline CK & 0 & 70 & 60 & Basal fertilization \\
FC & 250 & 70 & 60 & $\begin{array}{c}\text { Splitting fertiliza- } \\
\text { tion }\end{array}$ \\
RF & 210 & 70 & 60 & $\begin{array}{c}\text { Splitting fertiliza- } \\
\text { tion }\end{array}$ \\
CRF & 156 & 70 & 60 & Single fertilization \\
\hline
\end{tabular}

The management of pests, diseases, and weeds in each treatment was well controlled by farm managers.

\section{Soil sampling and analysis}

In each plot, four cores with $0.9 \mathrm{~m}$ depth were pooled to obtain a representative soil sample, homogenized, and passed through a $0.5-\mathrm{mm}$-diameter sieve. The nitrate contents from three soil layers (0-30, 30-60 and 60-90 cm depths) in each year were determined by extraction using $1 \mathrm{M} \mathrm{KCl}$ at a $1: 10$ ratio (ContinuousFlow Analysis-AA3 analyzer, Seal, Germany).

\section{Statistics analysis}

Statistical analysis was conducted with mixed analysis of variance (SAS software 2004) at the $5 \%$ significance level.

\section{Climate background}

Monthly rainfall, hours of sunshine, and average Max/ Min temperatures during the growing season (May-September) from 2004 to 2009 are shown in Fig. 2. Rainfall patterns experienced during the trial were different across years with heavy rainfalls recorded in 2008 and relative drought periods recorded in 2004, 2007 and
2009. The average annual rainfall in Dehui City, Northeast China, was $520 \mathrm{~mm}$, and $80 \%$ of the total rainfall occurred during May to September, which is the period during which maize requires the highest amount of water for germination. Rainfall in 2008 exceeded $50 \%$ of the average annual precipitation; and the rainfall in 2004, 2007 and 2009 was $15-20 \%$ less than normal.

\section{Results}

\section{Yield and N uptake}

Different treatments had significant differences in the yield and $\mathrm{N}$ uptake rates. For yield (Table 2), there was no significant difference for the fertilizer treatments in the 6-year field trials except for CK treatment. According to the statistical data, reduction of the nitrogen fertilizer rates (RF) and single fertilizer applications (CRF) had no effect on yield. In relation to nitrogen uptake (Table 3), the nitrogen uptake rates for the nitrogen fertilizer application treatments showed no significant differences in the long-term field trials. In the first year, there were no significant differences among the CK, FC, and RF levels, which was possibly due to the high soil fertility in Mollisol. The parameters of time, treatments, and their interactions significantly affected the yield and nitrogen uptake of maize (Table 4).

\section{Nitrate concentration in $\mathbf{0 - 9 0} \mathrm{cm}$ soil layer}

Time and treatments were the main contributing factors for nitrate accumulation in soil (Table 4). In Fig. 3, with the increasing rainfall, it was seen that rainfall and nitrate accumulation had no direct correlation; however, nitrogen uptake had significant correlation with rainfall.

The amount of accumulative nitrates in the soil profile $(0-90 \mathrm{~cm})$ across the years is depicted in Fig. 4. Soil nitrogen nitrates of fertilizer treatments were remarkably higher than those of the CK treatment, which implied that nitrogen fertilizer application increased the nitrate content in soil. Regarding the CK treatment, nitrate accumulation rates post-harvest in the successive 6-year field trials were lower than those before the broadcast, which resulted in nitrogen deficiency in soils. Nitrate residue peak in the $0-90 \mathrm{~cm}$ soil layer was $81.44 \mathrm{~N} \mathrm{~kg} / \mathrm{ha}$ by $250 \mathrm{~N}$ addition in long-term studies. Recommendation fertilizer rate (RF) and controlled release fertilizer (CRF) could decrease nitrate nitrogen in the $0-90 \mathrm{~cm}$ soil layer on average by 16.6 and $39.5 \%$, respectively, compared with the farmer conventional fertilizer (FC). A mitigating factor for the higher nitrate content of the CRF treatment recorded in 2004 was the increased hours of sunshine and poor rainfall throughout the year. The obvious lower rainfall in the rain-fed maize system impeded the release of CRF, which resulted in relatively higher nitrogen residues in the soil. 


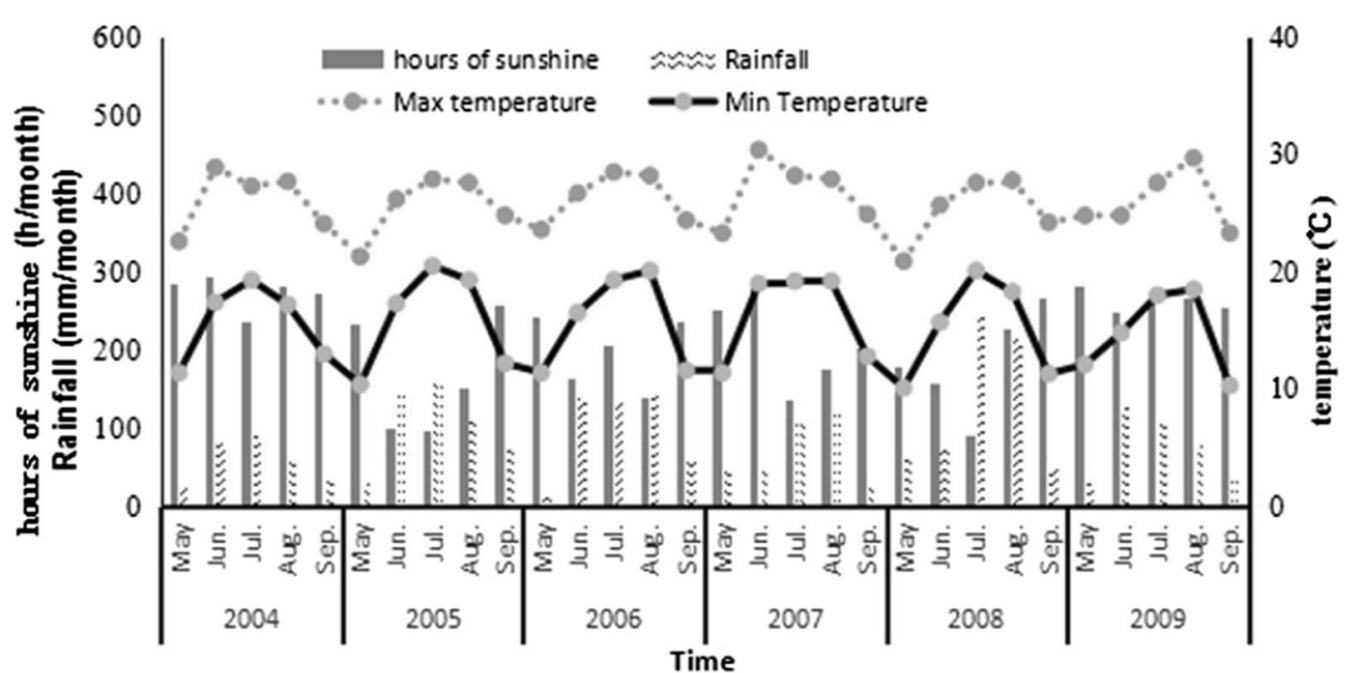

Fig. 2 Monthly rainfall (mm), hours of sunshine, and averaged Max/Min temperature during the growing season (May-September) from 2004 to 2009

Table 2 Average yields of different treatments during 2004-2009

\begin{tabular}{llrrr}
\hline Year & \multicolumn{1}{l}{ CK } & \multicolumn{1}{l}{ FC } & \multicolumn{1}{l}{ RF } & \multicolumn{1}{l}{ CRF } \\
\hline 2004 & $7.2 \pm 1.0 \mathrm{~b}$ & $9.2 \pm 0.8 \mathrm{a}$ & $9.2 \pm 0.5 \mathrm{a}$ & $8.9 \pm 0.9 \mathrm{a}$ \\
2005 & $6.8 \pm 1.4 \mathrm{~b}$ & $10.9 \pm 0.5 \mathrm{a}$ & $10.0 \pm 0.5 \mathrm{a}$ & $10.9 \pm 0.5 \mathrm{a}$ \\
2006 & $4.2 \pm 0.8 \mathrm{~b}$ & $13.6 \pm 0.7 \mathrm{a}$ & $13.7 \pm 0.7 \mathrm{a}$ & $13.6 \pm 0.9 \mathrm{a}$ \\
2007 & $4.3 \pm 0.4 \mathrm{~b}$ & $10.8 \pm 0.9 \mathrm{a}$ & $10.5 \pm 0.8 \mathrm{a}$ & $10.6 \pm 0.9 \mathrm{a}$ \\
2008 & $5.5 \pm 0.6 \mathrm{~b}$ & $10.2 \pm 1.6 \mathrm{a}$ & $11.1 \pm 0.8 \mathrm{a}$ & $10.9 \pm 0.6 \mathrm{a}$ \\
2009 & $4.8 \pm 0.8 \mathrm{~b}$ & $9.7 \pm 0.6 \mathrm{a}$ & $10.4 \pm 0.8 \mathrm{a}$ & $10.0 \pm 0.5 \mathrm{a}$ \\
\hline
\end{tabular}

Mean values in each line in the same year followed by different letters are significantly different at the 0.05 level

Table 3 Nitrogen uptake of different treatments during 2004-2009

\begin{tabular}{lllll}
\hline Year & CK & FC & RF & CRF \\
\hline 2004 & $129.8 \pm 28.5 b$ & $190.5 \pm 60.1 \mathrm{ab}$ & $178.8 \pm 32.2 \mathrm{ab}$ & $203.2 \pm 30.1 \mathrm{a}$ \\
2005 & $143.7 \pm 24 \mathrm{~b}$ & $200.4 \pm 42.3 \mathrm{a}$ & $221.9 \pm 23.3 \mathrm{a}$ & $192.5 \pm 24.5 \mathrm{a}$ \\
2006 & $61.6 \pm 9.0 \mathrm{~b}$ & $217.7 \pm 20.8 \mathrm{a}$ & $226.5 \pm 11.8 \mathrm{a}$ & $227.8 \pm 18.2 \mathrm{a}$ \\
2007 & $38.4 \pm 8.8 \mathrm{~b}$ & $164.8 \pm 33.4 \mathrm{a}$ & $164.2 \pm 5.1 \mathrm{a}$ & $145.0 \pm 10.4 \mathrm{a}$ \\
2008 & $86.2 \pm 11.5 \mathrm{~b}$ & $225.0 \pm 19.3 \mathrm{a}$ & $259.2 \pm 19.3 \mathrm{a}$ & $248.5 \pm 25.9 \mathrm{a}$ \\
2009 & $55.0 \pm 12.0 \mathrm{~b}$ & $153.4 \pm 17.6 \mathrm{a}$ & $202.0 \pm 34.9 \mathrm{a}$ & $134.4 \pm 9.7 \mathrm{a}$ \\
\hline
\end{tabular}

Mean values in each line in the same year followed by different letters are significantly different at the 0.05 level

\section{Nitrate changes of different treatments in soil profile}

From nitrate dynamic changes in the 6-year field trial (Fig. 5), it can be seen that nitrate content in the $0-30 \mathrm{~cm}$ soil profile was higher than those in the other profiles, especially for the FC and RF treatments. The main
Table 4 Analysis of variance (mean squares) of the soil nitrate content at harvesting, yield, and $\mathrm{N}$ uptake affected by years and fertilization managements

\begin{tabular}{lrr}
\hline Source & $\boldsymbol{d f}$ & Mean square \\
\hline Yield $\left(\mathrm{kg} \mathrm{ha}^{-1}\right)$ & & \\
Year $(\mathrm{Y})$ & 5 & $14,969,990.7^{* *}$ \\
Treatment $(\mathrm{T})$ & 3 & $169,835,958^{* *}$ \\
$\mathrm{Y} \times \mathrm{T}$ & 15 & $6,715,569.4^{* *}$ \\
N uptake $\left(\mathrm{kg} \mathrm{ha}^{-1}\right)$ & \\
$\quad$ Year $(\mathrm{Y})$ & 5 & $15,038.9^{* *}$ \\
Treatment $(\mathrm{T})$ & 3 & $76,425.2^{* *}$ \\
Y $\times \mathrm{T}$ & 15 & $2776.9^{* *}$ \\
Nitrate content $(0-90 \mathrm{~cm})\left(\mathrm{kg} \mathrm{ha}^{-1}\right)$ & \\
Year $(\mathrm{Y})$ & 5 & $1399.41^{* *}$ \\
Treatment $(\mathrm{T})$ & 3 & $8843.44^{* *}$ \\
Y $\times \mathrm{T}$ & 15 & $392.20^{* *}$ \\
\hline
\end{tabular}

** Significant at the 0.01 probability level

reason for the higher nitrate content in the surface soil was the top-dressing applied in the jointing stage, which increased the nitrate accumulation in topsoil when compared with the single fertilization treatment. However, the accumulated nitrate was lower in 2004 and 2007, and this phenomenon was possibly due to high temperature and shortage of rainfall. This resulted in ammonia volatilization loss by denitrification and perpetuated potential environmental risks.

At the $30-60 \mathrm{~cm}$ soil layer, nitrate accumulation ranged from $0.96 \mathrm{~kg} \mathrm{~N} / \mathrm{ha}$ (CK treatment in 2004) to $27.91 \mathrm{~kg} \mathrm{~N} /$ ha (FC treatment in 2008). Furthermore, soil nitrate 


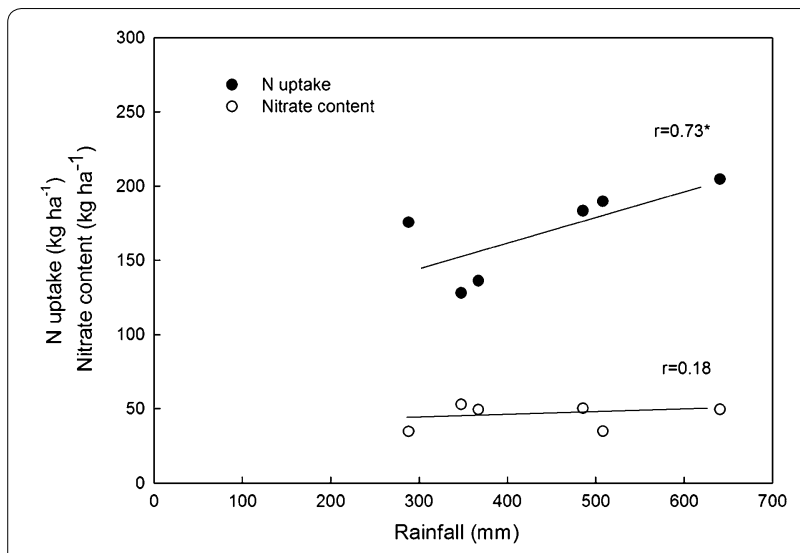

Fig. 3 Correlation analysis between rainfall and $\mathrm{N}$ uptake as well as nitrate content. * Significant at the 0.05 probability level

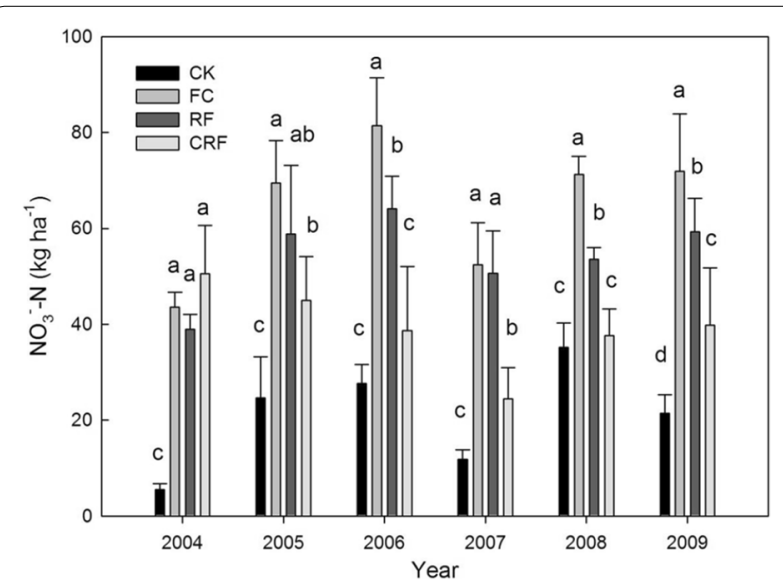

Fig. 4 Nitrate content in the soil profile $(0-90 \mathrm{~cm})$ for 6 years experiment in Northeast China

levels increased significantly in 2008, which is possibly related to extensive water movement during heavy rainfall periods, causing more $\mathrm{N}$ to leach deeper into the soil layers.

At the $60-90 \mathrm{~cm}$ soil layer, nitrate accumulation had a direct proportionality with time, increasing in trend as the years increased.

\section{Discussion}

In Northeast China, the use of single basal fertilization has increased in trend due to labor cost increasing exponentially [33, 34]; however, splitting fertilizer technology could increase the efficiency of fertilizer. Gao et al. [9] reported that in the maize belt in Jilin Province, plant areas of single fertilization already amounted to $62.5 \%$ of the total planted areas. Controlled release fertilizer, as a new single fertilization, not only minimized labor costs in farming systems [21], maintained the levels of nutrients over a relatively longer period, and increased nitrogen use efficiency [7], but also significantly reduced the nitrate accumulation when compared with the traditional fertilizer (Urea). Consequently, this study has similar results to and concurs with several other studies performed previously $[5,38]$.

The excessive application of $\mathrm{N}$ fertilizer is a common practice for ensuring maximum yields in maize planting systems in Northeast China. But Miao et al. [23] reported that by increasing cumulative nitrate $\mathrm{N}$ amounts, the seed yields and percentages increased by $\mathrm{N}$ addition rapidly declined, and when the cumulative nitrate amount was over $250 \mathrm{~N} \mathrm{~kg} / \mathrm{ha}$, there was no significant yield increase. In this trial, reducing fertilization treatment (RF) could work in harmony with the demand of crop as well as decrease nitrate accumulation risks.

Some researches in China showed that the concentration of nitrate residues in the $0-90 \mathrm{~cm}$ soils increased significantly with nitrogen application rates [17, 44]. Malhi et al. [22] surmised that the concentration of nitrate residue in soils was boosted by nitrogen application and could leach into the $90-\mathrm{cm}$ soil profile; conversely, by controlling the application of nitrogen, having no tillage and performing straw returning, this could control the accumulation of nitrogen in the soil profile. The results of this study showed that nitrate accumulation in the 0-90 $\mathrm{cm}$ soil profile in Northeast China ranged from 5.54 to $81.44 \mathrm{~N} \mathrm{~kg} / \mathrm{ha}$, and averagely $56 \mathrm{~N} \mathrm{~kg} /$ ha which was only $50 \%$ of the average value in Chinese farmlands [24]. The average nitrate accumulation in North China and South China was $120 \mathrm{~kg} / \mathrm{ha}$ and $133 \mathrm{~kg} / \mathrm{ha}$, respectively [24]. In European Union, the residue $N_{\min }$ was limited to lower than $90 \mathrm{~kg} / \mathrm{ha}$ in many countries [13]. In North China, Zhong et al. [43] suggested that the suitable residue $N_{\min }$ was an advantage of $\mathrm{N}$ absorption and utilization by the successive crop; however, they further added that residue levels should not exceed $150 \mathrm{~kg} / \mathrm{ha}$ in the winter wheat-summer maize rotation crop zone with high-yield and environmental protection. Therefore, in the continuous maize system in Northeast China, presently nitrate accumulation was within the rational levels. Furthermore, by reducing both the long-term fertilizer rate and controlled release fertilizer, the effect of fertilizer control was remarkable.

The amount of irrigation and rainfall influenced the nitrate accumulation peak in soil profiles. The analysis of the relationship between nitrate accumulation peak depth and rainfall in rain-fed agricultural regions with yearly $400-800 \mathrm{~cm}$ of rainfall was reported by Zhang [41]. The authors noted that there was a positive correlation between the peak depth of nitrate and rainfall; furthermore, peak depth focused on the $80-200 \mathrm{~cm}$ soil layer. A large of nitrate in soils would be leached to deeper soil 


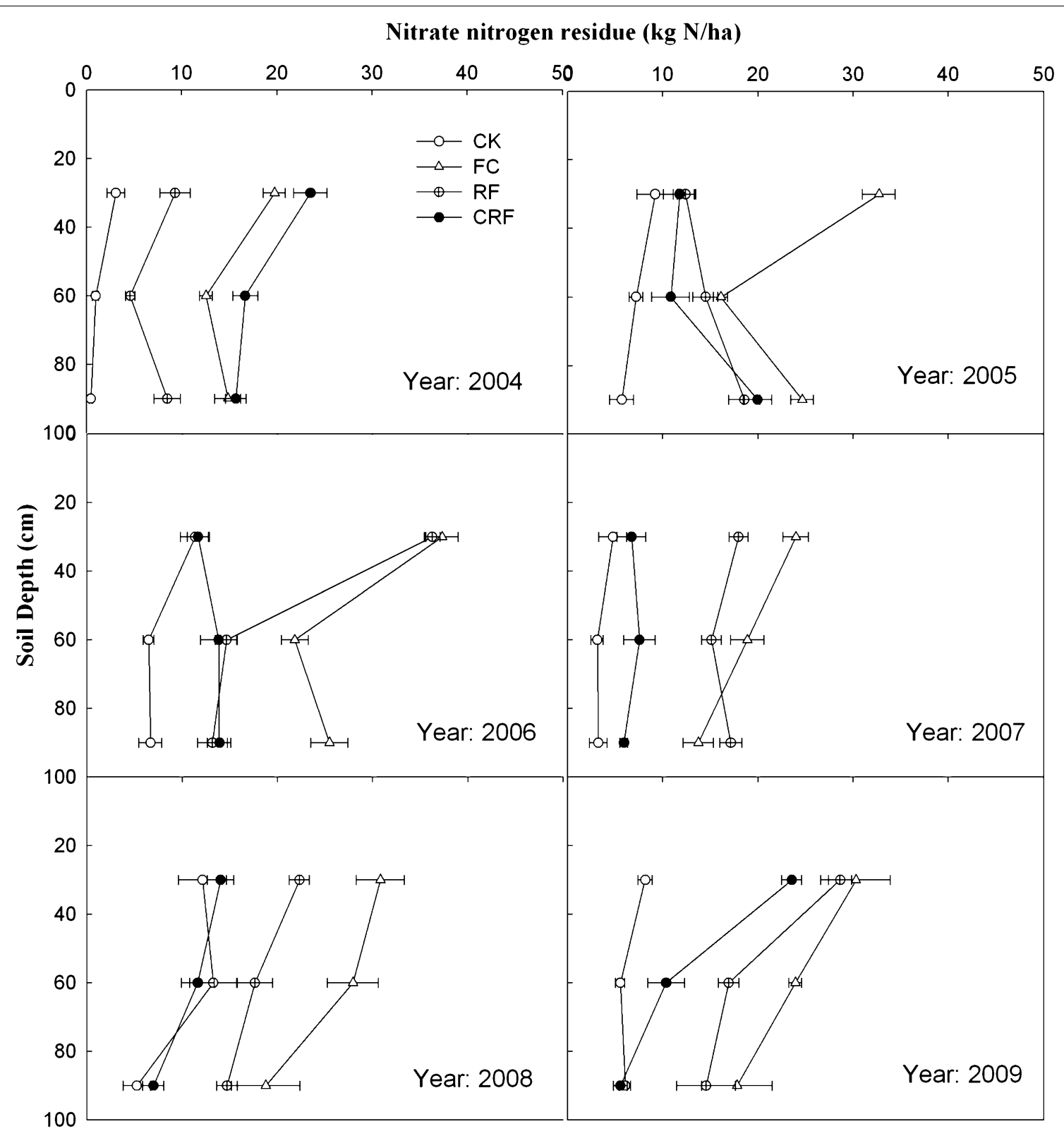

Fig. 5 Effect of different fertilization modes on yearly nitrate accumulation in different soil profiles $(0-30,30-60,60-90 \mathrm{~cm})$ in Northeast China. Error bars indicate the standard errors of mean (SE)

profile during periods of rainstorms and intense irrigation. Therefore, based on the above, it can be deduced that in this study there was a large possibility of the presence of nitrates in the deeper soil profiles.

\section{Conclusion}

Cumulative nitrate nitrogen in the $0-90 \mathrm{~cm}$ soil layer was associated with the application of nitrogen and precipitation in the rain-fed maize planting system. On average, the RF and CRF treatments decreased nitrate nitrogen by 16.6 and $39.5 \%$ in the $0-90 \mathrm{~cm}$ soil layer, respectively, and maintained a relatively high maize grain yield, when compared with the FC treatment. Under the arid climate, the application of controlled release fertilizer increased the accumulation of nitrate in soils due to a restraint in release. However, the high precipitation resulted in the leaching of nitrate into the deeper soil layer. The maximum of nitrate nitrogen in the $0-90 \mathrm{~cm}$ soil layer was $81.4 \mathrm{~kg} \mathrm{~N} / \mathrm{ha}$ at a nitrogen fertilizer rate of $250 \mathrm{~kg} \mathrm{~N} / \mathrm{ha}$ in the long-term trial, which was within the rational and safe 
levels for groundwater. Therefore, the best fertilization strategy to decrease nitrate accumulation in soil should consider both soil characteristics and precipitation.

\section{Authors' contributions}

LY and ZZ carried out the analysis of yield and nitrate changes, AMA analyzed the effect factors of nitrate, all steps were supervised by JZ and QG. All authors read and approved the final manuscript.

\section{Author details}

' College of Resource and Environmental Science, Jilin Agricultural University, Changchun 130118, People's Republic of China. ${ }^{2}$ Key Laboratory of Groundwater Resources and Environment, Ministry of Education, Jilin University, Changchun 130021, People's Republic of China.

\section{Acknowledgements}

The authors would like to acknowledge the National Maize (Zea mays L.) Production System in China and Special Fund for Agriculture Profession (201103003), the National Key Technology R\&D Program (2011BAD1 1B05, 2013BAD07B02), and the National Key Project of Water Pollution Control \& Management (2012ZX07201-001) for their financial support. We thank the anonymous reviewers for their valuable comments.

\section{Competing interests}

The authors declare that they have no competing interests.

Received: 16 September 2015 Accepted: 18 April 2016

Published online: 27 May 2016

\section{References}

1. Blankenau K, Olfs HW, Kuhlmann H. Strategies to improve the use efficiency of mineral fertilizer nitrogen applied to Winter wheat. J Agron Crop Sci. 2002:188:146-54

2. Cartegena MC, Vallejo A, Diez JA, Bustos A, Caballero R, Roman R. Effect of the type of fertilizer and source of irrigation water on $\mathrm{N}$ use in a maize crop. Field Crops Res. 1995;44:33-9.

3. Cui ZL, Zhang FS, Chen XP, Miao YX, Li JL, Shi LW, Xu JF, Ye YL, Liu CS, Yang ZP, Zhang Q, Huang SM, Bao DJ. On-farm evaluation of an in-season nitrogen management strategy based on soil $N_{\min }$ test. Field Crops Res. 2008:105:48-55.

4. Dai J, Wang ZH, Li FC, He G, Wang S, Li Q, Cao HB, Luo LC, Zan YL, Meng $X Y$, Zhang WF, Wang RH, Malhic SS. Optimizing nitrogen input by balancing winter wheat yield and residual nitrate-N in soil in a long-term dryland field experiment in the Loess Plateau of China. Field Crops Res. 2015;181:32-41.

5. Diez JA, Roman R, Caballero R, Caballero A. Nitrate leaching from soils under a maize-wheat-maize sequence, two irrigation schedules and three types of fertilizers. Agric Ecosyst Environ. 1997:6:189-99.

6. Dinnes DL, Karlen KL, Jaynes DB, Kaspar TC, Hatfield JL, Colvin TS, Cambardella CA. Nitrogen management strategies to reduce nitrate leaching in tile-drained Midwestern soils. Agron J. 2002:94:153-71.

7. Emilsson T, Berndtsson JC. Effect of using conventional and controlled release fertilizer on nutrient runoff from various vegetated roof systems. Ecol Eng. 2007;29:260-71.

8. FAO. FAOSTAT-Agriculture Database. http://faostat.fao.org/site/339/ default.aspx/. 2011. Updated 25 Feb 2011.

9. Gao Q, Li DZ, Huang LH, Piao CX, Wang JJ. Investigation of present situation on single fertilization for maize in Jilin maize belt. J. Jilin Agric Univ. 2008:30:301-5 (in Chinese)

10. Gao Q, Feng GZ, Wang ZG. Present situation of fertilizer application on spring maize in Northeast China. Chin Agric Sci Bull. 2010;26:229-31 (in Chinese)

11. Haderlein L, Jensen TL, Dowbenko RE, Blaylock AD. Controlled release urea as a nitrogen source for spring wheat in western Canada: yield, grain $N$ content, and N use efficiency. Sci World J. 2001;2:114-21.

12. He P, Li ST, Jin JY, Wang HT, Li CJ, Wang YL, Cui RZ. Performance of an optimized nutrient management system for double-cropped wheat-maize rotations in North-Central China. Agron J. 2009;101:1489-96.
13. Clercq DP, Hofman G, Jarvis SC, Neeteson JJ, Sinabel F, Gertsis A. Nutrient management legislation in European countries. Wageningen Pers; 2001.

14. Jia XC, Shao LJ, Liu P, Zhao BQ, Gu LM, Dong ST, Bing S, Zhang JW, Zhao B. Effect of different nitrogen and irrigation treatments on yield and nitrate leaching of summer maize (Zea mays L.) under lysimeter conditions. Agric Water Manag. 2014;137:92-103.

15. Ju XT, Xing GX, Chen XP, Zhang SL, Zhang LJ, Liu XJ, Cui ZL, Yin B, Christie $\mathrm{P}$, Zhu ZL, Zhang FS. Reducing environmental risk by improving $\mathrm{N}$ management in intensive Chinese agricultural systems. Proc Natl Acad Sci. 2009;106:3041-6.

16. Kou CL, Ju XT, Zhang FS. Nitrogen balance and its effects on nitrate-N concentration of groundwater in three intensive cropping systems of North China. Chin J Appl Ecol. 2005;16:660-7.

17. Liang BC, Mackenzie AF. Changes of soil nitrate-nitrogen and denitrification as affected by nitrogen fertilizer on two Quebec soils. J Environ Qual. 1994:23:521-5.

18. Liu JG, Diamond J. Revolutionizing China's environmental protection. Science. 2008:319:324-35.

19. Loepez-Bellido L, Muneoz-Romero V, Loepez-Bellido RJ. Nitrate accumulation in the soil profile: long-term effects of tillage, rotation and $\mathrm{N}$ rate in a Mediterranean Vertisol. Soil Tillage Res. 2013;130:18-23.

20. Luis LB, Veronica MR, Rafael JL. Nitrate accumulation in the soil profile: long-term effects of tillage, rotation and $\mathrm{N}$ rate in a Mediterranean Vertisol. Soil Tillage Res. 2013;130:18-23.

21. Maeda M, Zhao BZ, Ozaki Y, Yoneyama T. Nitrate leaching in an Andisol treated with different types of fertilizers. Environ Pollut. 2003:121:477-87.

22. Malhi SS, Nyborg M, Goddard T, Puurveen D. Long-term tillage, straw and $\mathrm{N}$ rate effects on some chemical properties in two contrasting soil types in Western Canada. Nutr Cycl Agroecosyst. 2011;90:133-46.

23. Miao YF, Zhang ZH, Li SX. Relation of nitrate $\mathrm{N}$ accumulation in dryland soil with wheat response to N fertilizer. Field Crops Res. 2015;179:119-30.

24. Ni YX. Nitrate accumulation, leaching, runoff and oxide emissions in Agricultural Soil of China. Baoding: Hebei Agriculture University. 2013 (in Chinese)

25. Roth GW, Fox RH. Soil nitrate accumulation following nitrogen-fertilized corn in Pennsylvania. J Environ Qual. 1990;19:243-8.

26. Qi T. The international competitiveness of corn in China. Ph.D thesis, Yangling: Northwest A\&F University; 2011 (in Chinese)

27. Shaviv A. Advances in controlled-release fertilizers. Adv Agron. 2001;71:1-49.

28. Statistics China. 2012. http://data.stats.gov.cn/workspace/index;jsession $\mathrm{id}=30$ B68ACED56F979E10E8ADD8131 C9AE9? $\mathrm{m}=$ fsnd. Statistics China, Beijing.

29. Sun B, Shen RP, Bouwman AF. Surface $N$ balances in agricultural crop production systems in China for the period 1980-2015. Pedosphere. 2008;18:304-15.

30. Sun B, Wang XX. Influencing factors of leaching nutrients in red soils. J Agro-Environ Sci. 2003;22:257-62.

31. Venterea RT, Rolston DE. Mechanisms and kinetics of nitric and nitrous oxide production during nitrification in agricultural soil. Glob Change Biol. 2000;6:303-16.

32. Wang X, Shi Y, Guo ZJ, Zhang YL, Yu ZW. Water use and soil nitrate nitrogen changes under supplemental irrigation with nitrogen application rate in wheat field. Field Crops Res. 2015:183:117-25.

33. Wang $\mathrm{YL}, \mathrm{Li} \mathrm{CH}$, He P. Nutrient restrictive factors and accumulation of super-high-yield summer maize. Plant Nutr Fertil Sci. 2006;16:559-66 (in Chinese).

34. Wang YL, Li CH, Tan JF, Han YL, Xu Z Studies on plant nitrogen accumulation characteristics and the effect of single application of base fertilizer on super-high-yield summer maize. Sci Agric Sin. 2006;43:2151-3158 (in Chinese).

35. Wang ZC. Effect of nitrate accumulation and dry-wet interaction process, Beijing: China Agricultural University; 2006 (in Chinese).

36. Wienhold BJ, Trooien TP, Reichman GA. Yield and nitrogen use efficiency of irrigated corn in the northern Great Plains. Agron J. 1995:87:842-6.

37. Yan $\mathrm{L}$, Zhang ZD, Zhang JJ, et al. Effects of improving nitrogen management on nitrogen utilization, nitrogen balance, and reactive nitrogen losses in a Mollisol with maize monoculture in Northeast China. Environ Sci Pollut Res. 2016. doi:10.1007/s11356-015-5684-z.

38. Yang JG, Gao Q, Cao B, Chen XP. Effect of single fertilization on spring maize yield and environment. Chin Agric Sci Bull. 2009:25:123-8 (in Chinese). 
39. Yang X, Lin E, Ma S, Ju H, Guo LP, Xiong W, Li Y, Xu YL. Adaptation of agriculture to warming in northeast China. Clim Change. 2007;84:45-58.

40. Yang YC, Zhang M, Zheng L, Cheng DD, Liu M, Geng YQ. Controlled release urea improved nitrogen use efficiency, yield, and quality of wheat. Agron J. 2011;103(2):479-85.

41. Zhang $\sqcup$. The behavior of residue nitrate and its utilization by plants in agro-ecosystem. Beijing: China Agriculture University; 2004 (in Chinese).

42. Zhang LP, Liao HX, Liu DL, Shao S. Effect of reducing nitrogen fertilizer rate in rotation of rice and rape. Hunan Agric Sci. 2010;5:47-9 (in Chinese)
43. Zhong Q, Ju XT, Zhang FS. Analysis of environmental endurance of winter wheat/summer maize rotation system to nitrogen in North China Plain. Plant Nutr Fertil Sci. 2006;12:285-93 (in Chinese).

44. Zhu ZL, Chen DL. Nitrogen fertilizer use in China-contributions to food production, impacts on the environment and best management strategies. Nutr Cycl Agroecosyst. 2002;63:117-27.

45. Ziadi N, Belanger G, Claessens A. Relationship between soil nitrate accumulation and in-season corn N nutrition indicators. Can J Plant Sci. 2012;92:331-9.

\section{Submit your manuscript to a SpringerOpen ${ }^{\circ}$ journal and benefit from:}

- Convenient online submission

- Rigorous peer review

Immediate publication on acceptance

- Open access: articles freely available online

- High visibility within the field

- Retaining the copyright to your article 